УДК 069.424:37

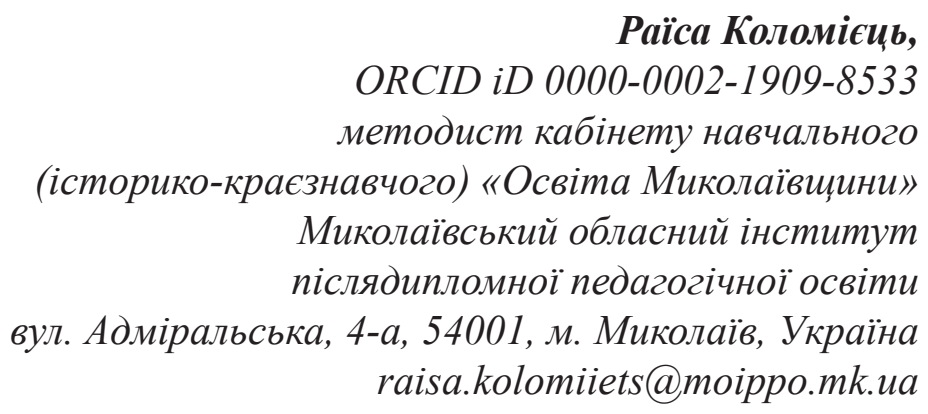

\title{
БЕРЕГИНЯ МУЗЕЮ «ЖИВОТОКИ»
}

Статтю присвячено дослідженню внеску Ганни Миколаївни Ковтун у розвиток історії та культури рідного краю, краєзнавства Снігурівщини Миколаївської області. Вона вдумливий учитель-краєзнавець, який багато років займається краєзнавчо-дослідницькою роботою разом із своїми вихованиями. Автор спробує висвітлити життєвий та творчий шлях учителя, який через усе своє життя проніс любов $і$ повагу до історичного розвитку рідного краю. Акцентовано увагу на тому, щуо діапазон краєзнавчих досліджень Ганни Миколаївни дуже широкий: історія, козащька доба на Снігурівщині, голодомор, релігія, культура, освіта, традииї та обряди бойків на Півдні України, відомі люди села Павлівка Снігурівського району Миколаӥвської області. Автор дослідив творчий шлях педагога-музейника, педагога-новатора, педагога-краєзнавия, який разом із своїми вихованиями зростає сам і навчає їх вести глибокий краєзнавчий пошук історії свого краю на прикладах життя односельчан, щзо тісно переплелося з історичним розвитком нашої Держави.

Висвітлено участь дітей украєзнавчих форумах, конференціях, конкурсах краєзнавчої тематики.

Ключові слова: виховання; дитина; екскурсї; експонати; збереження спадщини українського народу; краєзнавство; краєзнавчі експедицї; музеєзнавство; оригінальний музей.

СКоломієць Р. Ф., 2021

Людина в краєзнавстві є одночасно і творием, $і$ дослідником, і споживачем історії, охоронцем матеріальних і духовних иінностей краю.

Г. В. Бондаренко, учений, педагог із Волині

Вступ. Актуальність статті полягає в тому, щоб розповісти про людину, яка любить свій край, свою маленьку батьківщину, своє село, своїх батьків, свою хатину в селі, про Ковтун Ганну Миколаївну, учителя української мови та літератури, керівника музею «Животоки» Павлівського навчаль- но-виховного комплексу «загальноосвітній навчальний заклад I-III ступенів - заклад дошкільної освіти» Снігурівської міської ради Миколаївської області.

Сучасна освіта перебуває в постійному пошуку, прагне кращих прогресивних змін, але розвивати майбутнє, творити майбутнє, не вивчаючи історії України та своєї маленької батьківщини, неможливо. І оновлення музейної справи $є$ актуальним питанням для нашої країни, тому й вирішено здійснити переекспозицію історико-етнографічного музею «Животоки» Павлівського навчально-виховного комплексу «загальноосвітній навчальний заклад I-III ступенів 
- заклад дошкільної освіти» Снігурівської міської ради Миколаївської області з урахуванням усіх сучасних змін у суспільстві та освіті. Ганна Миколаївна підійшла до цього питання з великою відповідальністю, залучивши до оновлення експозиції художника-оформлювача та методистів обласного краєзнавчого музею «Флотські казарми» і Миколаївського обласного Центру туризму, краєзнавства та екскурсій учнівської молоді. У 2014 році Ганна Миколаївна Ковтун, учитель української мови та літератури Павлівської загальноосвітньої школи, керівник краєзнавчого гуртка «Животоки», визнана переможцем у регіональному конкурсі «Людина року Снігурівщини - 2014» у номінації «Освіта» (Благодатна 3. I., 2016, c. 2). Вона завжди пробуджує в дитини бажання творчо мислити, бажання дізнаватися нове, відшукувати істину в незвіданому просторі буття.

Мета статті полягає в ознайомленні вчителів із талановитим майстром, який має творче мислення, переймається відродженням української свідомості. Досягнення мети потребує виконання таких завдань: проаналізувати основні засади досвіду роботи педагогічного й учнівського колективів, популяризувати ефективні інноваційні форми і методи роботи 3 дітьми 3 питань пошукової діяльності в музеї, пропагувати новітні технології у вивченні та введенні до наукового обігу нових, ще не досліджених матеріалів із історії рідного краю.

Мова музею - мова оригіналу, першоджерело історичної інформації. Пам'ять про минуле допомагає правильно оцінювати сьогодення, осмислено працювати на майбутне (Майко С. М., 2017, с. 64). I Ганні Миколаївні це вдається на сто відсотків. Вона - талановитий краєзнавець, разом із своїми вихованцями досліджує змістове наповнення краєзнавчих напрацювань на матеріалах місцевих історичних подій; висвітлює напрацювання дитячих пошукових матеріалів на краєзнавчих форумах, конференціях, конкурсах.

Виклад основного матеріалу.

Знайомство з учителем відбулося ба- гато років тому, коли Ганна Миколаївна переконалася, що більше уваги необхідно приділяти поглибленим знанням 3 української мови та літератури, але не знала, який гурток із краєзнавства краще вибрати, щоби поєднати поглиблене вивчення свого улюбленого предмета 3 вивченням історії та українських традицій рідного краю. Вона розуміла, що може дати дітям набагато більше під час позаурочної роботи, подорожуючи рідним краєм. Ганна Миколаївна вміла навчати дітей особистісно сприймати й осмислювати художні твори, розуміти та відчувати красу мистецтва слова, осягнути сутність духовних цінностей, закладених в основу прочитаних текстів та побаченої краси рідної природи. Вона відчувала, що саме у процесі естетичних переживань, духовних осягнень, шкільного аналізу та інтерпретації тексту учні зуміють за допомогою вчителя сприймати художній текст яскравіше, переплітаючи свою розповідь 3 описами цікавих історичних подій рідного краю.

На той час прийнята наша порада взяти до уваги роботу під час занять у краєзнавчих гуртках «Юні музеєзнавці», або «Юні екскурсоводи», де діти матимуть можливість здобувати і поглиблювати знання з української мови та літератури, історії та культури рідного краю. Програми цих гуртків складені так, щоби поєднувати всі ці важливі моменти з професійністю Ганни Миколаївни.

Народилася Ганна Миколаївна Ковтун 12 грудня 1961 року в с. Павлівка Снігурівського району Миколаївської області. До першого класу Павлівської середньої школи Ганна Миколаївна вступила у 1969 році, яку закінчила у 1979 році. За період навчання брала участь у художній самодіяльності, у шкільних, районних олімпіадах з української мови та літератури. Уже на шкільній ниві Ганна виявляла глибокі знання з української мови та літератури. Тому і вибір подальшого навчання був вирішеним.

У 1979 році вступила до Миколаївського державного педагогічного інституту 
імені В. Г. Бєлінського, проте життя внесло свої корективи. I в 1981 році Ганна Миколаївна вийшла заміж та перевелася до Дрогобицького педагогічного інституту імені I. Я. Франка, який закінчила у 1983 році та здобула спеціальність учителя української мови і літератури. Після закінчення інституту працювала вихователем ГПД у Новороздільській середній школі № 4.

Iз 1986 року переїжджає в Херсонську область разом із своїм чоловіком та трирічним сином Павлом. Працює вчителем української мови i літератури в Трестівській середній школі Чаплинського району Херсонської області. У зв'язку з сімейними обставинами знову переїжджає разом із сім'єю в Миколаївську область до Снігурівського району в с. Павлівка. Г. М. Ковтун працює у Павлівській загальноосвітній школі I-III ступенів із 1991 року вчителем української мови, літератури та краєзнавства, а з 1998 року очолює роботу історико-краєзнавчого музею «Животоки».

Музей «Животоки» Павлівської загальноосвітньої школи I-Ш ступенів Снігурівської міської ради Миколаївської області засновано у 1989 році директором школи В. О. Подскрипко та заступником директора $з$ виховної роботи В. В. Братченко. Спочатку це був етнографічний куточок, де формувалася етнографічна колекція, який згодом переріс в етнографічну світлицю. А 30 січня 1998 року завдяки наполегливій праці Ганни Миколаївни музей «Животоки» зареєстровано при закладі системи Міністерства освіти України. Останню реекспозицію проведено у 2016 році у двох нових кімнатах на другому поверсі.

«А наш музей - то особливий світ, де все живе, вирує, діє.

Тут почуттів, думок політ, всі сподівання і надї»-

так про свій музей говорить Ганна Миколаївна. Музей $є$ осередком освіти і виховання, сприяє формуванню в молодого покоління національної свідомості, любові до рідної землі, свого народу, забезпечує духовну єдність поколінь. 7-ий рік триває війна на Сході України. Наша українська земля об- стрілюється російськими бойовиками, яку нині захищають воїни ООС, а ми, вчителі, маємо виховувати в дітей почуття гідності, почуття патріотизму. Прищеплюючи учням любов до рідного краю, ми формуємо гідне майбутне нашого народу. I тут на перший план виходить робота музею, що покликана сприяти вдосконаленню освітнього процесу школи, розширенню і поглибленню освітньої та професійної підготовки учнів, розвитку їхніх творчих інтересів до пошуково-краєзнавчої, науково-дослідницької роботи. Ганна Миколаївна підтримує висловлювання Н. Філіпчук про те, «... що реалізація соціальної місії музеїв, освітніх завдань освітньої діяльності різних музеїв (історичного, літературного, місцевого) забезпечується на основі постійних оновлення змісту, форм і методів педагогічної освітньої взаємодії музею та навчальних закладів. Це вимагає професійної підготовки музейних викладачів у закладах вищої педагогічної освіти» (Філіпчук Н., 2020, № 2, с. 62).

Музей складається 3 двох кімнат, загальна площа яких 91 м $^{2}\left(70\right.$ м² $^{2}, 21$ м $\left.^{2}\right)$, «...i створений у 1989 році учнями Павлівської школи під керівництвом директора школи В. О. Подскрипко та заступника директора з виховної роботи В. В. Батечко».

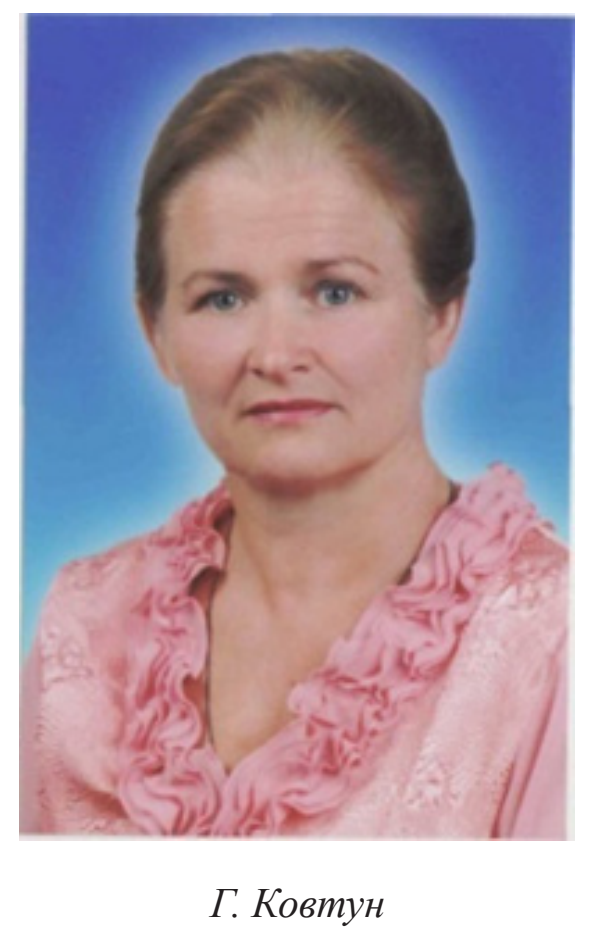


«Оформлення музейних експозицій проведено у хронологічному порядку з визначенням основних тематичних розділів, що відповідають профілю музею (історико-етнографічний)» (Коломієць Р. Ф., 2010, c. 5). I кожним музейним предметом Ганна Миколаївна доводить те, що будь-який експонат є носієм неповторної історії. А вміння зібрати і захопливо розповісти цю історію дітям - це завдання вчителя. Учитель непомітно, через розповідь виховує патріота, керує процесом належної змістової наповненості заняття, зорієнтовує на новизну інформації та різноманітні види пошукової, розвивальної, творчої діяльності. Формує пошану, любов до рідного слова, переконує учнів в усвідомленні мови як найдорожчого скарбу, у якому втілені національна свідомість, характер, історія народу. I всі ці якості притаманні Ганні Миколаївні Ковтун, яка досконало володіє майстерністю під час своїх занять прищеплювати дітям любов до рідного краю, української мови, національної культури.

«Ідеї національно-патріотичного виховання є домінантними не лише на уроках учителя-словесника, а й у позакласній роботі, де Ганна Миколаївна використовує такі методи роботи, як: вечори народної пісні і танцю, свята рідної мови, виставки народних промислів, свята 3 використанням українських традицій, обрядів, звичаїв, зустрічі з цікавими людьми, пішохідні екскурсіі, інтелектуальні ігри. Опора на ці методи сприяє формуванню у вихованців патріотичних почуттів, любові до рідної землі, виховує честь, гідність, відвагу, прагнення пізнавати, зберігати й передавати у спадок надбання народу» (Волос О. В., Длінна T. I., 2006, с. 50).

Для учнів Павлівської школи стало традицією щороку вшановувати пам'ять видатного українського гумориста і сатирика, справжнього громадянина України Павла Глазового. Так, Гончар Владислав, учень 3 класу, узяв участь у XV обласному конкурсі «Сміхослов» і виборов III місце, в обласному конкурсі поезії В. Бойченка Катерина Воткаленко - I місце, Александрова
Лідія - III місце.

Ганні Миколаївні вдається залучити дітей до вивчення духовних надбань предків, їхніх народних традицій, національної історії українського народу. І всі ці численні заходи Ганна Миколаївна проводить у музеї, серед експонатів, до яких учитель не лише дозволяє доторкнутися, а й самим написати свою історію того чи іншого предмета. Такий спосіб опису предмета розвиває уяву, допомагає поєднувати знання історії й культури з українським словом, його красою, милозвучністю, мелодійністю. Наприклад, в експозиції демонструються різної форми глиняні макітри та макогони, якими наші предки терли мак. У музеї зібрана досить велика колекція різних прасок - для прасування білизни, дерев'яні ночви - для прання одягу, гребінь - для розчісування льону. Ганна Миколаївна спочатку ознайомлює вихованців з експонатом, потім дає дітям завдання вивчити інформацію про цей предмет у літературі та вікіпедії, після чого написати свою думку про використання цього предмета в народному побуті.

«Створення музею - це своєрідна творча справа великого колективу вчителів, учнів, односельців. За кожною фотографією стоїть історія цілого покоління. За кожним предметом - епоха, події» (Коломієць Р. Ф., 2010, с. 5). Місцевий краєзнавчий матеріал допомагає учням краще розібратися в особливостях національного характеру нашого народу, сприяє вихованню поваги до національної культури, мови, традицій. Учитель уміло знайомить учнів iз родинними архівами, які люб'язно приносять жителі села до музею на тимчасове зберігання, пояснює зв'язок людини 3 минулими і майбутніми поколіннями, виховує розуміння сенсу життя, інтерес до родинних і народних традицій. Ганна Миколаївна намагається не зупинятися на досягнутому. Музей постійно поповнюється новими оригінальними експонатами, матеріалами, які учні збирають під час краєзнавчих експедицій та зустрічей із цікавими людьми краю. Результатом діяльності в музеї пошукового загону щодо збирання мате- 
ріалів про учасників операції Об'єднаних сил є оформлення нової експозиції «Україна - єдина». Різнозмістова експозиція музею дає можливість проводити музейні уроки, навчально-практичні конференції, семінари, класні години, краєзнавчі квести, зустрічі з ветеранами війни та праці, цікавими і талановитими людьми.

Упродовж багатьох років Ганна Миколаївна очолює краєзнавчі гуртки «Животоки», «Юні музеєзнавці», «Юні екскурсоводи», що діють при Павлівському НВК, головне завдання яких - готувати молоде покоління до самостійного життєвого вибору та перспектив майбутнього. Вихованці гуртка упродовж навчального року збирали фольклорний матеріал, писали науково-дослідницькі роботи, проводили презентації малюнків «Рідна земля очима переселенців 1951 року», вивчали народні ремесла, українські традиції і свята. 3 особливим трепетом розпитували старожилів села про переселення бойків у Південні степи. Оскільки Ганна Миколаївна сама а з родини переселенців, «... тому з любов’ю зберігає і розповідає дітям про унікальні реліквії - свідоцтва релігійного життя бойків на історичній батьківщині, землі якої відійшли за міждержавним договором 1951 року до республіки Польща, а населення було примусово розсіяне степами Півдня та Сходу України» (Длінна Т. I., 2016, с. 1).

«Важливу роль в етнічному, духовному та культурному самозбереженні бойків на чужині відіграли віра та духовні традиції. Про це свідчать збережені релігійні реліквії: дві вівтарні ікони з храму Святого Миколая Чудотворця в селі Ялове (нині територія Польщі) та інші експонати краєзнавчого музею «Животоки» Павлівської школи. Одна 3 них - ікона Ісуса Христа, дідусь учениці 8 класу Пташник Олі, ікону відреставрував і тепер вона стала оберегом музею» (Длінна Т. I., 2016, с. 2).

Автору довелося брати участь в одній iз таких краєзнавчих експедицій у селі Павлівка. Нашим завданням було зібрати матеріали про особливості весільного обряду бойків. I під час експедиції ми побачили неперевершений талант Г. М. Ковтун, яка вирізнялася неабиякою тактовністю, терпінням і вмінням направляти просту жінку у правильне русло розмовної ріки спогадів і пережитого трагізму. Ганна Миколаївна розповіла про своїх батьків, які були уродженцями Ялового та Замлиння - сіл Нижньо-Устрицького району, колишньої Дрогобицької області.

Переселенці не втрачали віри і завдяки повсякденній праці зуміли вижити в чужому краї. Призвичаїлися до місцевого клімату, а звичаї свої не забували. Наприклад, весілля бойків-переселенців обов'язково проходило через релігійну святиню, через ікони, які вони зберігали і ховали від радянської влади. Про все це пізніше напише У. Поверінова у своїй науково-дослідницькій роботі «Збереження традицій весільної обрядовості бойків на Миколаївщині» (керівник Р. Ф. Коломієць). Завдяки захисту цієї роботи Уляна стала переможцем Миколаївської міжрегіональної краєзнавчої конференції «Мій край - моя земля, очима сучасників» (2006-2007рp.); переможцем Запорізької краєзнавчої конференції учнівської молоді (2006-2007рр.); переможцем III етапу Всеукраїнського конкурсу-захисту наукових учнівських робіт МАН (секція «Етнологія», ІІ місце) (2007-2008 рр.).

Вихованці Ганни Миколаївни теж ставали активними учасниками і переможцями Всеукраїнських історико-краєзнавчих, туристсько-краєзнавчих експедицій. Так, у грудні 2014 року в місті Миколаєві вони навчались у школі юних краєзнавців «3 думою про рідний край». Члени гуртка гідно представили Снігурівщину і стали переможцями у квест-грі краєзнавчого орієнтування «Визначні місця міста розповідають». 09-11 грудня 2016 року гуртківці взяли участь у Міжрегіональній зустрічі краєзнавців «Єднаймося заради України».

Із великою повагою Ганна Миколаївна розповідає про своїх вихованців, які протягом багатьох років беруть активну участь у Всеукраїнській філософській історико-краєзнавчій конференції учнівської 
молоді «Пізнай себе, свій рід, свій нарід» (м. Харків). Серед них - І. Ридош, М. Ревуцька, А. Мисик, А. Іщенко, Ю. Кравченко, А. Мацюта, А. Поскрипка, С. Гошкович, А. Борисевич, А. Бохонок, О. Предчук, В. Білан. 17 грамот, подяк і дипломів отримали вони від Харківського центру туризму. Гуртківці брали активну участь у I-VII Всеукраїнських краєзнавчих конференціях «Мій рідний край, моя земля очима сучасників». С. Гошкович і А. Борисевич були запрошені на фінал III Всеукраїнського історичного конкурсу «Непізнана історія мого краю» (м. Львів).

Шість років поспіль гуртківці Г. М. Ковтун беруть участь в обласному конкурсі «Музейна скарбниця Миколаївщини», посідаючи призові місця. Катерині Воткаленко, учениці 8 класу, пощастило взяти участь у II турі Всеукраїнського конкурсу екскурсоводів музеїв навчальних закладів «Край, в якому я живу» (м. Київ). Катерину нагороджено дипломом і цінним подарунком.

Учень, що цікавиться краєзнавством, може вибрати собі заняття до душі. Вивчення краєзнавства зрештою допомагає дітям вибрати свою майбутню професію, так уважає Ганна Миколаївна. Традиційні форми і методи краєзнавчої роботи: походи, екскурсії, зустрічі, поїздки (в архів, музей, бібліотеки), конференції, участь у конкурсах, фестивалях, виставках; робота 3 книгою, із документом, робота $з$ батьками; участь у Всеукраїнських експедиціях: «Моя Батьківщина - Україна», «Мій рідний край»; акція «Збережемо пам'ять про подвиг», «Орден у моєму домі», «Напиши листа ветерану», «Зігрій солдата»; «Уявна бесіда $з$ воїном АТО».

Найголовніше в організації краєзнавчої роботи - допомогти учням відчути відповідальність за долю рідного краю. Результатом роботи навчально-виховного комплексу є випускник, у якого сформовано рівень соціальної зрілості, творча особистість із розвиненою потребою в самовдосконаленні, з почуттям відповідальності за долю України ії народу, людства.
Із величезним сумом проходять у школі зустрічі з учасниками АТО (випускниками школи). Незабутнім був захід із волонтером Інною Володимирівною Гошкович. Краєзнавчо-пошукова робота учнів $є$ першим кроком залучення їх до науково-дослідницької діяльності, профорієнтації на майбутні професії. Г. М. Ковтун вірить, що прийшов той час в Україні, коли кожна родина буде дотримуватись українських звичаїв, одягати українське вбрання, «від колиски» співати дітям українські пісні, шанувати рідну мову.

Висновки. Аналізуючи діяльність Ковтун Ганни Миколаївни у вивченні краєзнавства, звертаючи увагу на особливості реформування сучасної освітньої галузі, можемо констатувати, що сучасний український педагог в особі Ганни Миколаївни активно популяризує вивчення не лише свій улюблений предмет, а й сприяє розвитку музейної педагогіки через різноманітні заняття з краєзнавства. Ідеї індивідуального диференційованого підходу до створення різних форм своїх занять стали основним стрижнем у розбудові музею Павлівської школи. Підсумовуючи діяльність керівника музею «Животоки», можна впевнено сказати, що експозиція музею відповідає викликам часу, а Ганна Миколаївна втілює в життя кращі музейні інновації та інтерактивність. Ганна Миколаївна продовжує працювати в школі, із дітьми збирає краєзнавчі матеріали, облікує, описує їх в інвентарній книзі музею. Через статті, через наукові роботи МАН Г. М. Ковтун уводить зібрані музейні матеріали в науковий обіг, що допомагає науковцям досліджувати невідомі сторінки історії рідного краю. А музейні інновації, що використовує Ганна Миколаївна - це використання мультимедійних технологій в експозиційному просторі музею для підсилення інформативності, комунікативності та атрактивності музейної експозиції, а також використання комп'ютерного програмування $з$ метою вдосконалення обліку та використання музейних фондів. Це допомагає дітям якісно підготувати науково-дослідницькі роботи для Малої академії 
наук та статей до місцевої газети.

Перспективою дослідження $є$ ви- світлення досвіду відомих музейних працівників, учителів.

\section{ЛІТЕРАТУРА}

1. Благодатна 3. I. Краєзнавча робота - шлях до пізнання історії народу 3. I. Благодатна // Снігурівка. РДА. Новини. 29.02.2016. - Режим доступу: snigurivka-rda.gov.ua〉 humanitarian $>$ news

2. Волос О. В., Длінна Т. І. Науково-методичні поради щодо організації краєзнавчої роботи з учнівською молоддю / О. В. Волос, Т. І. Длінна. - Миколаїв : ОІППО. - 2006. $64 \mathrm{c}$.

3. Длінна Т. І. Бойки на Снігурівщині: збережені святині. / Т. І. Длінна // Голос Снігурівщини. 4.05.2016. - Режим доступу: golosnigurivshchini.golos.mk.ua@gmail.com

4. Коломієць Р. Ф. Народознавчий музей «Животоки» - невід’ємна складова навчально-виховного процесу Павлівської ЗОШ Снігурівського району / Р. Ф. Коломієць. - Миколаїв. - 2010.- 30 с.

5. Майко С. М. Шкільний музей як форма додаткової освіти / С. М. Майко // Педагогічний пошук. Науково-методичний вісник. - 2017. - № 2. - С. 64.

6. Філіпчук Н. Музейна педагогіка як теоретична основа педагогічно-освітньої діяльності культурно-освітніх установ // Професійна освіта впродовж життя у ХХІ столітті / Н. Філіпчук // Вісник кафедри ЮНЕСКО. - 2020. - № 2. - С. 62. Doi.org/10.35387/ ucj.2(2).2020.61-70

\section{ХРАНИТЕЛЬНИЦА МУЗЕЯ «ЖИВОТОКИ»}

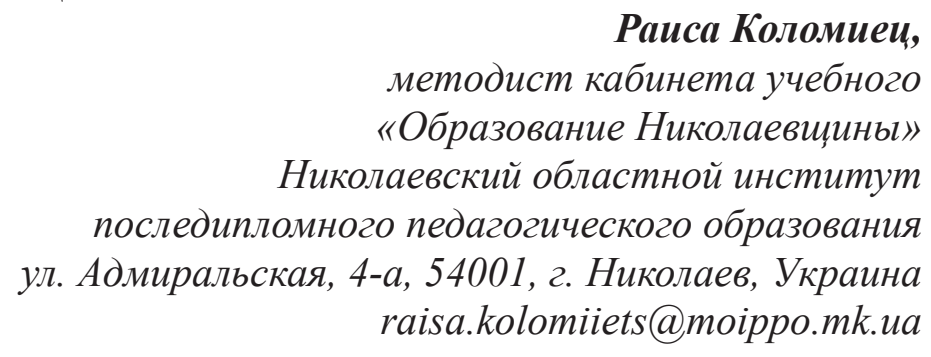

Статья посвящена исследованию вклада Анны Николаевны Ковтун в развитие истории и культуры родного края, краеведения Снегиревщины Николаевской области. Она - вдумчивый учитель-краевед, который много лет занимается краеведческо-исследовательской работой вместе со своими воспитанниками.

Автором предпринята попытка исследования жизненного и творческого пути учителя, который на протяжении всей своей жизни пронес любовь и уважение к историческому развитию родного края. Акиентировано внимание деятельности на том, что диапазон краеведческих исследований Анны Николаевны очень широк: история, казаџкая эпоха на Снегиревщине, голодомор, религия, культура, образование, традиции и обрядь бойков на юге Украины, известные люди села Павловка Снегиревского района Николаевской области. Личность Анны Николаевнь очень многогранная, это педагог-музейщик, педагог-новатор, педагог-краевед, который вместе со своими воспитанниками растет сам и учит их вести глубокий краеведческий поиск истории родного края на примерах жизни односельчан, жизнь которых тесно переплелась с историческим развитием нашего государства. В тексте освещены исследования учащихся, их наработки и участие в краеведческих форумах, конференциях, конкурсах краеведческой тематики.

Ключевые слова: воспитание; краеведение; краеведческие экспедици; музееведение; музей; оригинальные экспонаты; сохранение наследия украинского народа; экскурсии. 


\title{
KEEPER OF “ZHIVOTOKI” MUSEUM
}

\author{
Kolomiets Raisa, \\ educator of the office of the local history \\ «Education of Mykolaiv region» \\ Mykolaiv In-Service Teachers Training Institute \\ 4-a Admiralska Street, 54001, Mykolaiv, Ukraine \\ raisa.kolomiiets@moippo.mk.ua
}

The article is devoted to the research of Anna Kovtun's contribution to the history and cultural development of the native land and local lore of the Snihuriv area of Mykolayiv region. She is a thoughtful teacher and a local historian who has been engaged in local history research with her students for many years.

The author will highlight the life and creative path of this teacher.

Also, the teacher managed to organize the collection of materials covering the participation of fellow villagers in the war in eastern Ukraine. Through the exhibits of the museum, Anna tells about the difficult period of independent Ukraine and makes every effort to help soldiers including knitting socks for those who are on the front line of the combat zone, organizing sweets fairs, baking cakes for combatants, congratulations soldiers with their professional holidays, collecting signatures on the Ukrainian flag to transfer it to the front line and meetings with participants of the anti-terrorist operation and volunteers.

It was on the initiative of the teacher-museologist to open an interesting exhibition of children's drawings, beadwork (angels), samples of chevrons of those who took part in the undeclared Russian war against Ukraine.

The author made an attempt to study the creative path of an innovative teacher-museologist, local historian, who along with her pupils conducted a deep local history search for the region. history. The author highlights children's participation in local lore forums, conferences, and competitions.

Keywords: education; excursions; local history expeditions; local lore; museum; museum studies; original exhibits; preservation of the Ukrainian heritage.

\section{REFERENCES}

1. Blahodatna, Z. I. (2016). Kraieznavcha robota - shliakh do piznannia istorii narodu [Local lore work - a way to learn about the history of the people]. Snihurivka. RDA. 29.02.2016 Retrieved from: snigurivka-rda.gov.ua〉 humanitarian〉 news (ukr).

2. Dlinna, T. I. (2016). Boiky na Snihurivshchyni: zberezheni sviatyni [Fights in the Snihuriv region: preserved shrines.]. Holos Snihurivshchyny. 4.05.2016. Retrieved from: golosnigurivshchini.golos.mk.ua@gmail.com (ukr).

3. Filipchuk, N. (2020). Muzeina pedahohika yak teoretychna osnova pedahohichnoosvitnoi diialnosti kulturno-osvitnikh ustanov [Museum pedagogy as a theoretical basis of pedagogical and educational activities of cultural and educational institutions]. Profesiina osvita vprodovzh zhyttia u XXI stolitti. Visnyk kafedry YuNESKO, 2, 62. Doi.org/10.35387/ ucj.2(2).2020.61-70 (ukr).

4. Kolomiiets, R. F. (2010). Narodoznavchyi muzei «Zhyvotoky»-nevidiemna skladova navchalno-vykhovnoho protsesu Pavlivskoi ZOSh Snihurivskoho raionu [Museum «Zhyvotoky» - an integral part of the educational process of Pavlovsk Secondary School of Snihuriv district]. Mykolaiv (ukr).

5. Maiko, S. M. (2017). Shkilnyi muzei yak forma dodatkovoi osvity [School Museum as a form of additional education]. Pedahohichnyi poshuk. Naukovo-metodychnyi visnyk, 2, 64. (ukr). 
6. Volos, O. V. \& Dlinna, T. I. (2006). Naukovo-metodychni porady shchodo orhanizatsii kraieznavchoi roboty $z$ uchnivskoiu moloddiu [Scientific and methodical advice on the organization of local lore work with students]. Mykolaiv: OIPPO (ukr).

\section{Інтер'ср залу музею «Животоки»}
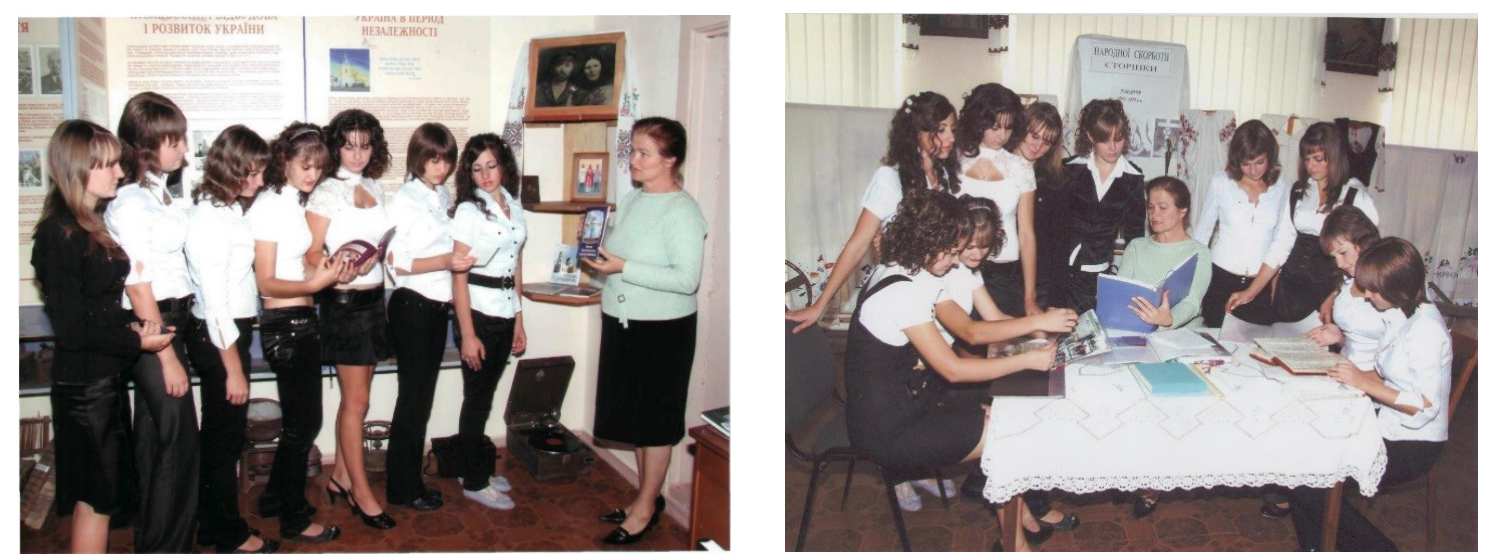

Павлівська загальноосвітня школа. 2015 р. Г. М. Ковтун зі своїми вихованщями

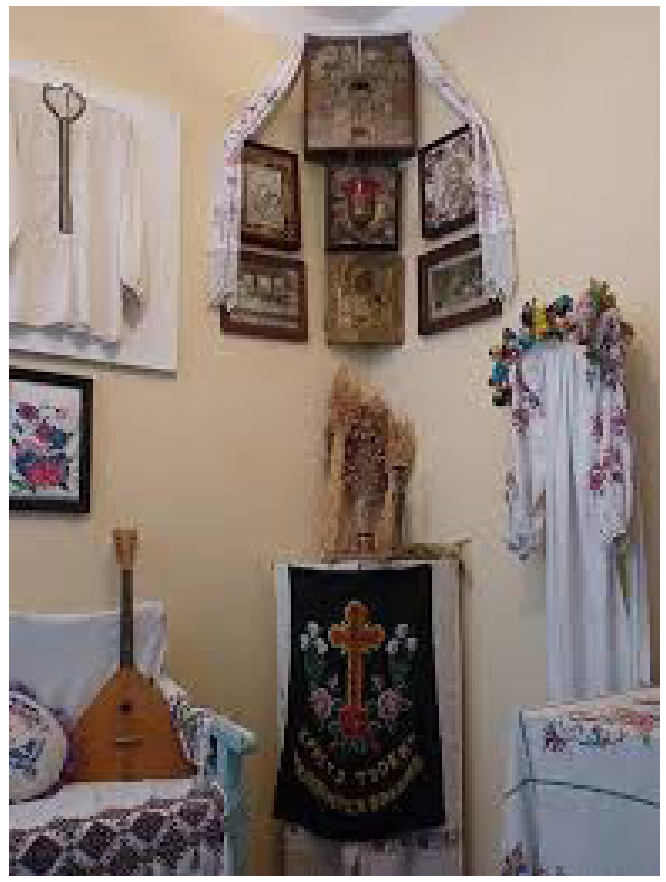

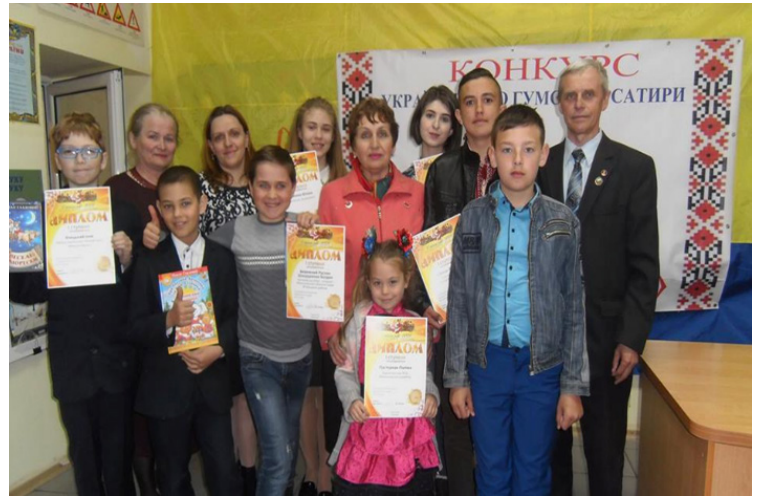

Задоволені і щзасливі вихованці Ганни Миколаївни

Павлівська загальноосвітня школа. Музей «Животоки». 2015 p. 